\title{
Biogeography of Medically Important Insects using Quantitative Analysis
}

\author{
By Qi Shen, Zhixing You, Xiaojing Ma \& Xiaocheng Shen \\ Henan University of Traditional Chinese Medicine
}

Abstract- We summarized distributional information of medically important insects from 76 families and 4531 genera occurring worldwide. The continents were divided into 67 basic geographical units. Using a new similarity formula and a new clustering method for quantitative analysis, 67 basic geographical units were clustered into 7 large unit groups and 20 small unit groups. The results were superior to the traditional single linkage method, average group linkage method, or sum of squares method. The cluster results were similar with the result of mainly phytophagous insects 104,344 genera in the world, but were different from the Wallace's mammal geographical division scheme. Based on these seemingly contradictory results, we infer that animals, insect and plants may have the same distribution pattern and that it is necessary to conduct precise quantitative analysis for animals and plants worldwide.

Keywords: biogeography; medical important insect; similarity general formula; multivariate similarity clustering analysis.

GJMR-G Classification: NLMC Code: WC 900

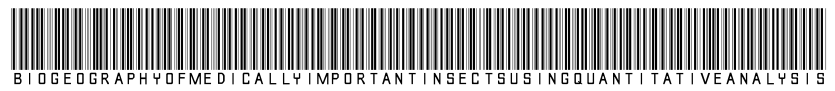

Strictly as per the compliance and regulations of:

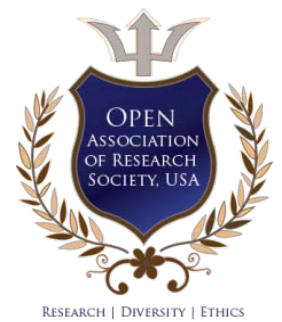

(C) 2020. Qi Shen, Zhixing You, Xiaojing Ma \& Xiaocheng Shen. This is a research/review paper, distributed under the terms of the Creative Commons Attribution-Noncommercial 3.0 Unported License http://creativecommons.org/licenses/by-nc/3.0/), permitting all non-commercial use, distribution, and reproduction in any medium, provided the original work is properly cited. 


\title{
Biogeography of Medically Important Insects using Quantitative Analysis
}

\author{
Qi Shen ${ }^{\alpha}$, Zhixing You ${ }^{\sigma}$, Xiaojing Ma ${ }^{\rho} \&$ Xiaocheng Shen ${ }^{\omega}$
}

\begin{abstract}
We summarized distributional information of medically important insects from 76 families and 4531 genera occurring worldwide. The continents were divided into 67 basic geographical units. Using a new similarity formula and a new clustering method for quantitative analysis, 67 basic geographical units were clustered into 7 large unit groups and 20 small unit groups. The results were superior to the traditional single linkage method, average group linkage method, or sum of squares method. The cluster results were similar with the result of mainly phytophagous insects 104,344 genera in the world, but were different from the Wallace's mammal geographical division scheme. Based on these seemingly contradictory results, we infer that animals, insect and plants may have the same distribution pattern and that it is necessary to conduct precise quantitative analysis for animals and plants worldwide.
\end{abstract}

Keywords: biogeography; medical important insect; similarity general formula; multivariate similarity clustering analysis.

\section{INTRODUCTION}

T here are three categories of medically important insects: insects that feed on the blood of warm blooded animals (humans, mammals, and birds) and can transmit disease; insects that feed on the fur, feathers, and skin secretions of animals and birds, irritating the host; insects that live in the habitats of humans, mammals and birds, causing irritation and sometimes transmitting diseases. Since these insects have a close relationship with mammals and birds, they may have the same geographical distribution pattern with the mammals described by Wallace (1876). Computer and Internet technology has made it possible to collect and analyze large data sets and re-evaluate previous Wallace's scheme which are based on qualitative analysis (Olson et al., 2001; Procheş, 2005; Cox, 2010; Kreftet al., 2010; Procheşet al., 2012; Rueda et al., 2013; Whittaker et al., 2013; Holt et al., 2013; Peixotoet al., 2017). Kreftet al. (2010) and Holt et al. (2013) both used Simpson similarity formula and the UPGMA method for quantitative analysis of mammalian species distribution but they obtained different results.

Author $\alpha$ : First Clinical College, Henan University of Traditional Chinese Medicine, Zhengzhou, China.

Author $\sigma$ : Academy of Mathematics and Systems Science, Beijing, China.

Author $\rho$ w: Institute of Plant Protection, Henan Academy of Agricultural Sciences, Zhengzhou, China. e-mail: shenxiaoc@126.com
Different geographical division schemes for some insect orders and families have been proposed (Herman et al., 2001; Evans, 2007; Balianet al., 2008; Moor et al., 2008; Morse et al., 2011; Taegeret al., 2010). The results of most of these studies did not support the "Wallace line", that is Wallace's great contribution to the field. Among them, as medical important insects, Culinidae and Siphonaptera geographic division settings are also proposed the same questions (Siver, 2004; Vashchonovet al., 2013). The extensive attention and indepth discussion in biogeography interpretation provides an exciting opportunity for evaluating insect distributions and geographical division plans.

We used the similarity general formula (SGF) proposed by Shenet al. (2008a) and multivariate similarity clustering analysis (MSCA) (Shenet al., 2008b) for quantitative analysis of the medically important insects in China (Shen, 2014). The results were unexpectedly similar to the results of all (93661) insect species in China (Shenet al., 2013a; 2013b; 2015), but different from the results of a Chinese mammalian species geographical division, made using qualitative analysis (Zhang, 2011). To study the relationship between the global distributions of medically important insects, phytophagous insects, and mammals, we used a variety of quantitative methods for this analysis.

\section{il. Materials and Methods}

\section{a) Global medically important insect species}

We used medically important insect distribution data from four resources: (1) World species and distribution data collected and summarized by entomologists, e.g. Knight et al., 1977, Durden et al., 1994, Currie et al., 2008, Adler et al., 2014; (2) Data from specific countries and regions, e.g. Seccombe et al., 1993, De Carvalho et al., 2005, Coscarón et al., 2008, Crespo et al., 2010, Chahari et al., 2015, Wolff et al., 2016, Takano et al., 2017; (3) Data from organizations studying biodiversity and academic websites, such as Beccdloni, 2014, Borkent, 2014, Pickering, 2014, Evenhuis, 2016, GBIF, 2017; (4) Recently published data for new species and new distribution records, such as Gustafsson et al.,2015, Najer et al., 2016, Szelag et al., 2016, Fuenzalidaet al., 2017, Huerta et al., 2017, Natarajanet al., 2017, Vidlčkaet al., 2017. The data cited above did not include marine species or fossil records. In total, 9 orders, 67 families, 4531 genera and 63470 species were included (Table 1). This was $4.3 \%$ of the 
total number of insect genera and $6.1 \%$ of the total insect species in the world. Because insects have small bodies, their species distribution is narrower compared with higher animals and plants (Shenet al., 2018). To improve the data utilization ratio and accuracy of the analysis, the genus was used as the basic biological unit (BBU).

Table 1: Global medically important insect species used for analysis

\begin{tabular}{|c|c|c|c|c|}
\hline Orders & No. of families & No. of genera & No. of species & Main data sources \\
\hline Blattodea & 8 & 490 & 4428 & $\begin{array}{l}\text { Roth, 2003, Vidlička, 2013, 2017, Beccdloni, 2014, } \\
\text { Vrsansky, 2010, 2012, } 2013\end{array}$ \\
\hline Mallophaga & 9 & 485 & 4565 & Mey, 2004, Pickering, 2014, Gustafsson, et al., 2015 \\
\hline Anoplura & 14 & 46 & 553 & Durden et al., 1994, Sánchez-Montes et al., 2013 \\
\hline Hemiptera & 1 & 22 & 74 & Usinger, 1966,Iorio, 2012, GBIF, 2019c \\
\hline Coleoptera & 1 & 126 & 2480 & $\begin{array}{l}\text { GBIF, 2019a } \\
\text { Knight et al., 1977, Seccombe et al., 1993, Currie, 2008, }\end{array}$ \\
\hline Diptera & 16 & 2337 & 36594 & $\begin{array}{l}\text { Adler et al., 2014,Borkent, 2014,Henriques, 2016, } \\
\text { Evenhuis, 2016, Takaoka et al., 2017, GBIF, 2019b }\end{array}$ \\
\hline Siphonaptera & 20 & 241 & 2099 & $\begin{array}{l}\text { Acosta, 2003, Hastriteret al., 2006, Lewis et al., } \\
\text { 2013,Vashchonoket al., 2013,Beaucournuet al., } 2014\end{array}$ \\
\hline Lepidoptera & 2 & 544 & 5969 & GBIF, 2019e \\
\hline Hymenoptera & 5 & 440 & 6708 & GBIF, 2019d \\
\hline Total & 76 & 4531 & 63470 & \\
\hline
\end{tabular}

b) Division of basic geographical units (BGU) and building the databank

According to the terrain, climate, and other ecological conditions, we have divided the continents (except Antarctica) into 67 basic geographical units (BGU) (Fig. 1). Of these BGUs, 21 BGUs were mainly plain, 11 were mainly hills, 12 were mainly mountain, 11 were mainly plateau, five were mainly desert and seven were mainly islands. A total of 27 BGUs were in tropical zone, 34 were in temperate zones and six were extended to the frigid zone. The names and geographical ranges of the BGUs are listed in Table 2.
We used Microsoft Access as our database software. Each BGU was listed as the column and BBU was listed as the row. The distribution of different species belonging to the same genus was transferred to the BGU and summarized as the genus distribution. During the data entry, when there was a distribution, it was marked as 1; if there was no distribution, no record was entered. These basic distributional records (BDR) were the basis of quantitative analysis. Each BGU insect genus number is listed in Table 2.

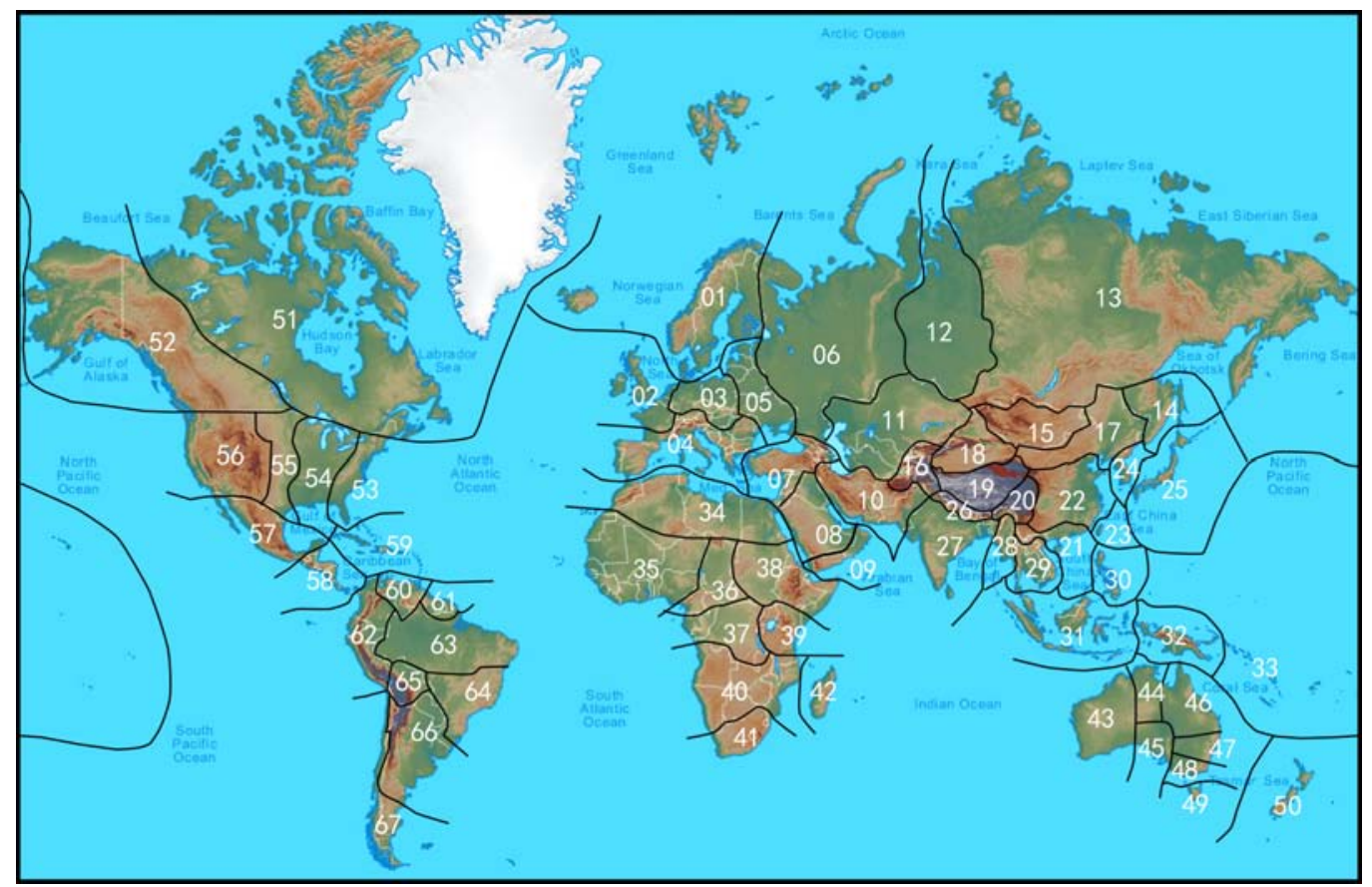

Fig. 1: BGUs of the World 
01 Northern Europe, 02 Western Europe, 03 Central Europe, 04 Southern Europe, 05 Eastern Europe, 06 European Russia, 07 Middle East, 08 Saudi Arabia, 09 Yemen and Oman, 10 Plateau of Iran, 11 Central Asia, 12 Western Siberia, 13 Eastern Siberia, 14Ussuri region, 15 Mongolia, 16 Plateau of Pamir, 17 Northeastern region of China, 18Northwestern region of China, 19 Qinghai-Xizang region of China, 20 Southwestern region of China, 21 Southern region of China, 22 Centre-eastern China, 23 Taiwan region of China, 24 Korea Peninsula, 25 Japan, 26 Himalayan region, 27 Indian and Sri Lanka, 28 Myanmar, 29 Indochina Peninsula, 30 Philippines, 31 Indonesia, 32
New Guinea, 33 Islands of Pacific Ocean, 34 Northern Africa, 35 Western Africa, 36 Central Africa, 37 Congo river basin, 38 Ethiopia region, 39 Tanzania region, 40 Angola region, 41 South Africa, 42 Madagascar, 43 Western Australia, 44 Northern Territory, 45 South Australia, 46 Queensland, 47 New South Wales, 48 Victoria, 49 Tasmania, 50 New Zealand, 51 Eastern Canada, 52 Western Canada,53 Mts. Eastern US, 54 Plain Central US, 55 Hills Central US, 56 Mts. Western US, 57 Mexico, 58 Central America region, 59 Caribbean Islands, 60 Venezuela, 61 Plateau Guyana, 62 Northern Mt. Andes, 63 Amazon Plain, 64 Plateau Brazil, 65 Bolivia, 66 Argentina, 67 Southern Mt. Andes

Table 2: The number of medical important insect genera of BGUs in the World

\begin{tabular}{cccccccc}
\hline BGU & Number of genera & BGU & Number of genera & BGU & Number of genera & BGU & Number of genera \\
\hline 01 & 253 & 19 & 310 & 37 & 207 & 55 & 242 \\
02 & 316 & 20 & 457 & 38 & 131 & 56 & 323 \\
03 & 245 & 21 & 474 & 39 & 241 & 57 & 325 \\
04 & 271 & 22 & 614 & 40 & 251 & 58 & 459 \\
05 & 99 & 23 & 419 & 41 & 292 & 59 & 133 \\
06 & 143 & 24 & 125 & 42 & 180 & 60 & 179 \\
07 & 208 & 25 & 300 & 43 & 116 & 61 & 173 \\
08 & 81 & 26 & 161 & 44 & 101 & 62 & 376 \\
09 & 75 & 27 & 310 & 45 & 79 & 63 & 263 \\
10 & 211 & 28 & 214 & 46 & 239 & 64 & 239 \\
11 & 246 & 29 & 284 & 47 & 232 & 65 & 150 \\
12 & 165 & 30 & 201 & 47 & 135 & 66 & 235 \\
13 & 315 & 31 & 343 & 49 & 151 & 67 & 74 \\
14 & 124 & 32 & 179 & 50 & 71 & BBU & 4531 \\
15 & 103 & 33 & 168 & 51 & 205 & BGU & 67 \\
16 & 127 & 34 & 209 & 52 & 256 & BDR & 15450 \\
17 & 446 & 35 & 222 & 53 & 299 & AR & 231 \\
18 & 314 & 36 & 139 & 54 & 233 & ADT & 3.41 \\
\hline
\end{tabular}

${ }^{*} A R$ (average richness): $B D R / B G U:{ }^{*} A D T$ (average distributional territory): $B D R / B B U$

\section{c) Clustering methods}

Shen's SGF is defined as follows: similarity coefficient among multiple regions is the ratio of the average species number shared by all regions to the total species number (Shenet al., 2008a):

$$
S I_{n}=\sum H_{i} / n S_{n}=\sum\left(S_{i}-T_{i}\right) / n S_{n}
$$

In this formula, $S I_{n}$ is the similarity coefficient of $n$ BGUs: $S_{i}, H_{i}$ and $T_{i}$ are $i$ BGU species number, common species number and unique species number, respectively, and $H_{i}=S_{i}-T_{i}: S_{n}$ is the total species number in $n$ BGUs. For calculation, all values were obtained from the database search page. This was convenient for both manual and computer calculations.

The MSCA indicated that the similarity coefficient of any group could be calculated directly and not restrained by the clustering order. It even was possible the first to calculate the total similarity coefficient of the 67 BGUs.

For example, we calculated the similarity coefficient of four BGU from Europe (Fig. 2). The 4066 in the first column of the first row was the number of genera that have not distribution by all four BGUs. The first number in other each column was the unique species number of every BGU. The number 465 , which was the total genus number 4531 minus 4066, was the total species number of all five BGUs. The genus numbers of four BGUs were 253, 316, 245, and 271 as shown in Table 2. Using a calculator for these steps $253+316+245+271-30-59-7-68=921$, dividing by 4 , then dividing by 465 , produced a similarity coefficient 0.495. The process was simple compared to the processes of other clustering methods. 


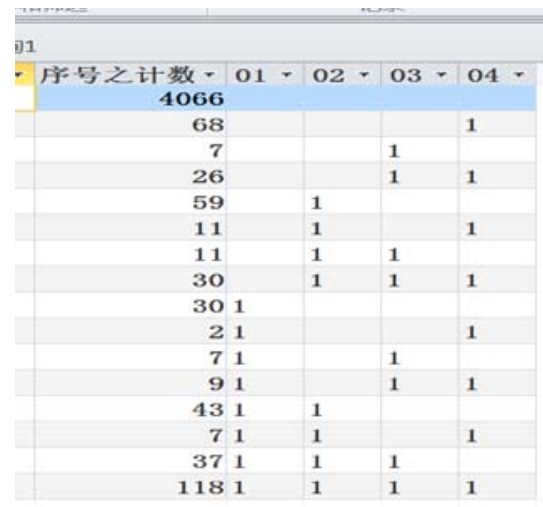

Fig. 2: Screen cut for calculating No. 01-04 BGU similarity coefficient

To compare the analysis results, three of the most common hierarchical clustering methods were used (Kreft, 2010):

1) The single linkage method, also called nearest neighbor method, using the Jaccard (1901) similarity formula: $\mathrm{SI}=\mathrm{C} /(\mathrm{A}+\mathrm{BC})$, which was the most basic clustering method;

2) Average group linkage method, which was also called unweighted pair group means algorithm (UPGMA) method, using the Szymkiewicz (1934) similarity formula, also called the Simpson (1947) formula: $\mathrm{SI}=\mathrm{C} / \mathrm{min}(\mathrm{A}, \mathrm{B})$, which is the most popular clustering method.

3) Sum of squares method (Ward's method), using the Czekanowski (1913) similarity formula (also called Sørensen (1948) formula): $\mathrm{SI}=2 \mathrm{C} /(\mathrm{A}+\mathrm{B})$. Using this method, better results can be obtained, but the calculation process is complicated.

The three similarity formulas were subjected to pairwise comparisons. $A$ and $B$ were species numbers in two regions and $\mathrm{C}$ was the species number shared by two regions.

\section{ili. Results}

MSCA clustering results (Fig. 3) showed that the 67 BGUs total similarity coefficient was 0.089 . At 0.370 similarity coefficient level, 67 BGUs were clustered as at 20 small unit groups, at 0.250 similarity coefficient level, 20 small unit groups were clustered as A-G 7 big unit groups. Unit of each group was neighbor and connected to each other, corresponding to the geographical principles. The similarity level was greater within the group than among different groups and the ecological condition of each group was independent, corresponding to the principles of statistics and ecology.

Clustering results showed high consistency with world insects clustering results (Shenet al., 2018). The numbers of big and small unit groups were the same, components of each big and small group were almost the same, and the structures between the groups were consistent. One difference was that the total similarity coefficient and similarity level of large and small unit groups of medically important insects were higher than all insects. This may be because medically important insects have generated more attention and research. The clustering location of individual units had moved: Unit 25\# moved from the $\mathrm{g}$ small unit group to the $f$ small unit group. Unit $37 \#$ moved from the h small unit group to the i small unit group. Unit 74\# moved from the $r$ small unit group to the $s$ small unit group. These movements were between neighboring groups, consistent with geographical principles.

We compared mammalian division scheme (Wallace, 1876) and except for the D big unit group that was the same in the Ethiopian realm, all other groups were different. $A$ and $B$ big unit groups divided the Palearctic realm into east and west sections. $\mathrm{C}$ and $\mathrm{E}$ big groups incorporated New Guinea and Pacific islands from the Australian realm into the Oriental realm. $F$ and $G$ big groups incorporated Central America in the Neotropic realm into the Nearctic realm.

Compared with current world plant division proposed by Cox (Cox, 2001), the C, D, E big unit groups were the same as the India-Pacific kingdom, Afritropic kingdom, and Australian kingdom. The difference was that the $A, B$ and $F$ big unit groups divided the Holarctic realm into three parts. $F$ and $G$ big groups categorized Central America in the Neotropic kingdom into the Nearctic kingdom.

Compared with the current several insect groups division, our results support the following: the Palearctic realm is divided into two parts by Trichoptera and Aleyrodidae(Morse et al., 2011; Evans, 2007). The Siphonaptera and Trichopteracategorize New Guinea and the Pacific Islands into the Oriental realm (Vashchonoket al., 2013; Moor et al., 2008). The results also support separating Pacific Islands from the Australia realm by Staphylinidae, Aleyrodidaeand aquatic insects (Herman et al., 2001; Evans, 2007; Balianet al., 2008); incorporation of Yemen and Oman into the Palearctic realm by Symphyta and Culicidae (Taegeret al., 2010; Silver, 2004); And incorporation of Mexico into Nearctic realm by the Culicidae (Silver, 
2004). However, the results did not support assigning New Zealand, Madagascar and Antarctic as separate realms.

The traditional methods did not produce accurate, sensitive, and precise results. The results of the single linkage method (Fig. 4) were chaotic with no distinct layers. Many geographical units could not be clustered, such as units 20,31, 49, 58,69, 78, that were called "noise". The average group linkage method (Fig. 5) was better than the single linkage method and removed most of the "noise". At the distant level of 0.63 the BGUs could be clustered into six unit groups, five of which had significant geographical meaning. The letters corresponding to the areas in Fig. 3, the largest group which was composed of 26 BGUs, were chaotic and lacked geographical values. More precise division did not improve this. The sum of squares method (Fig. 6) had better clustering results. At the distance of 1.2, the BGUs could be clustered into eight groups and the first seven had geographical meaning. The last group did not conform to the principle of geography and it was difficult to achieve precise clustering.

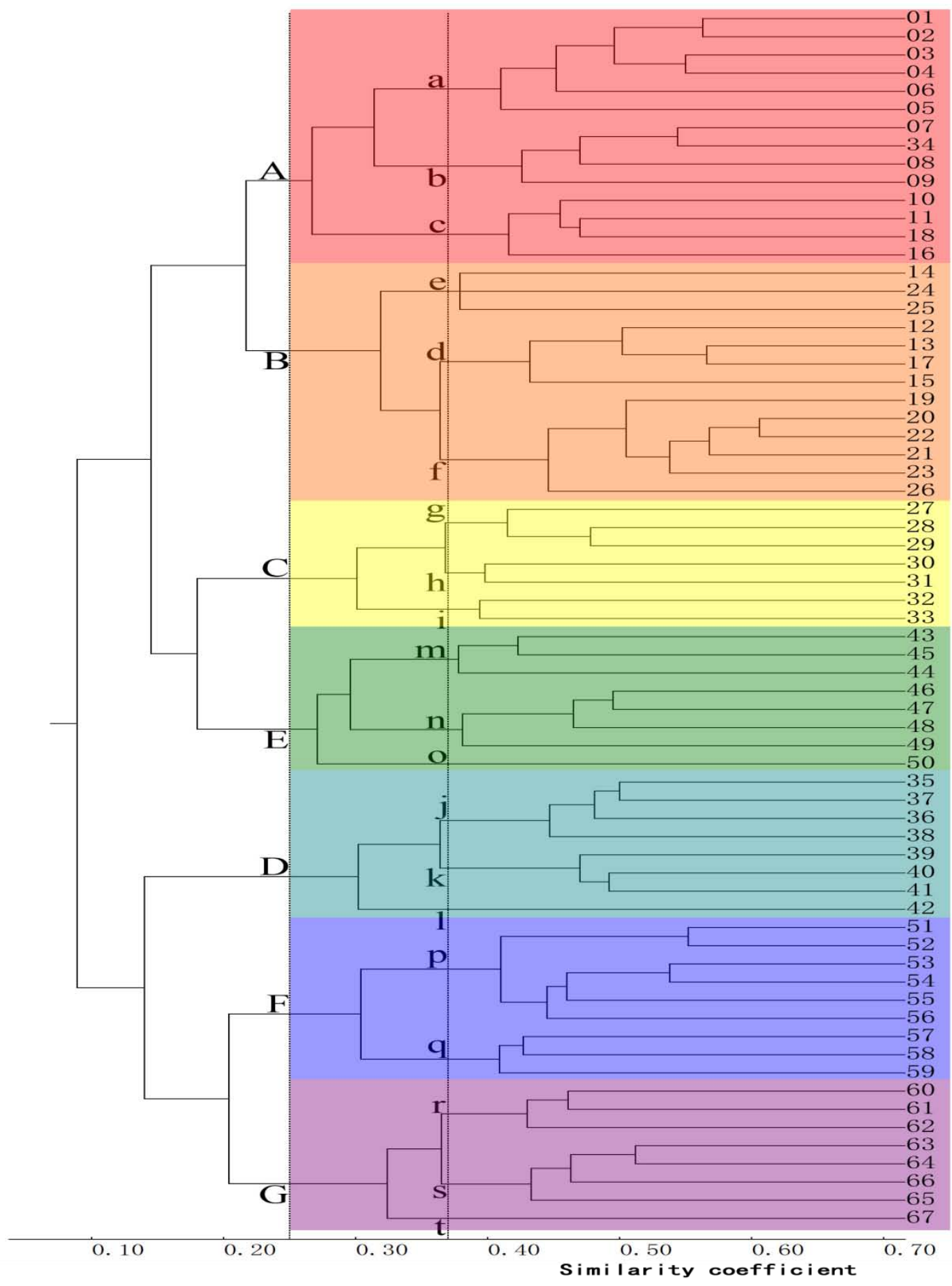

Fig. 3: Clustering tree of Medical insect of World by MSCA 


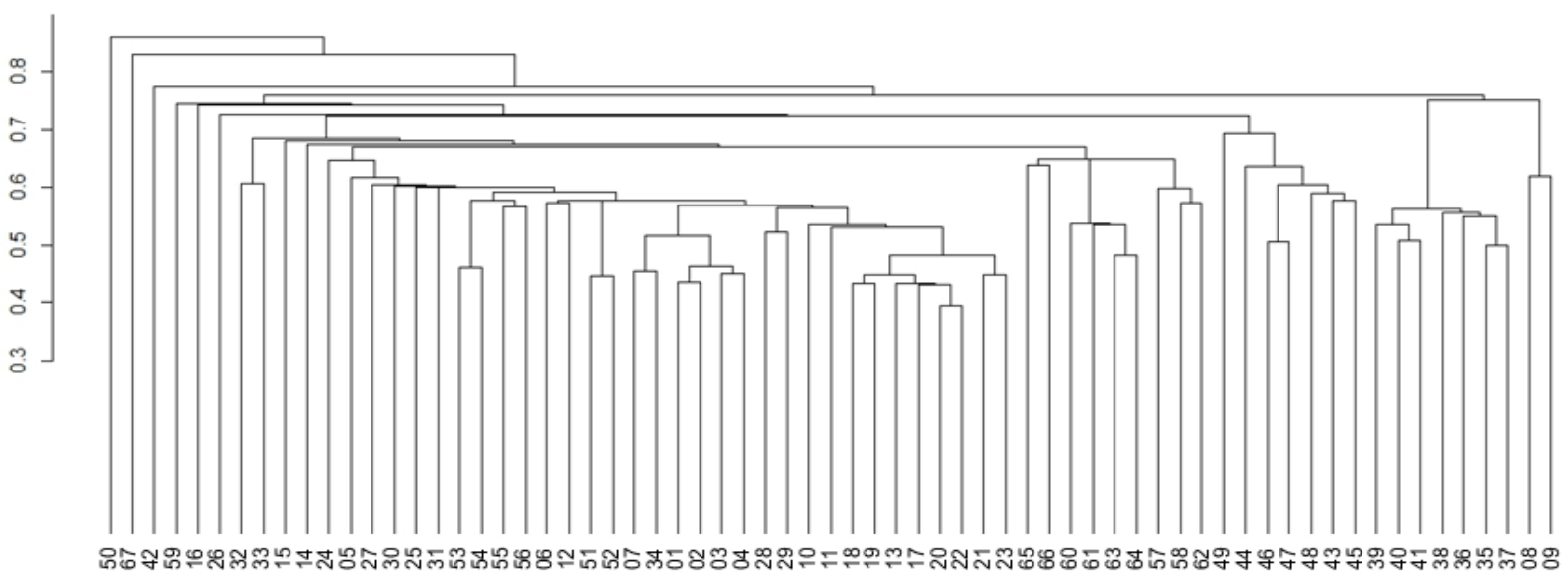

Fig. 4: Clustering tree by single linkage method

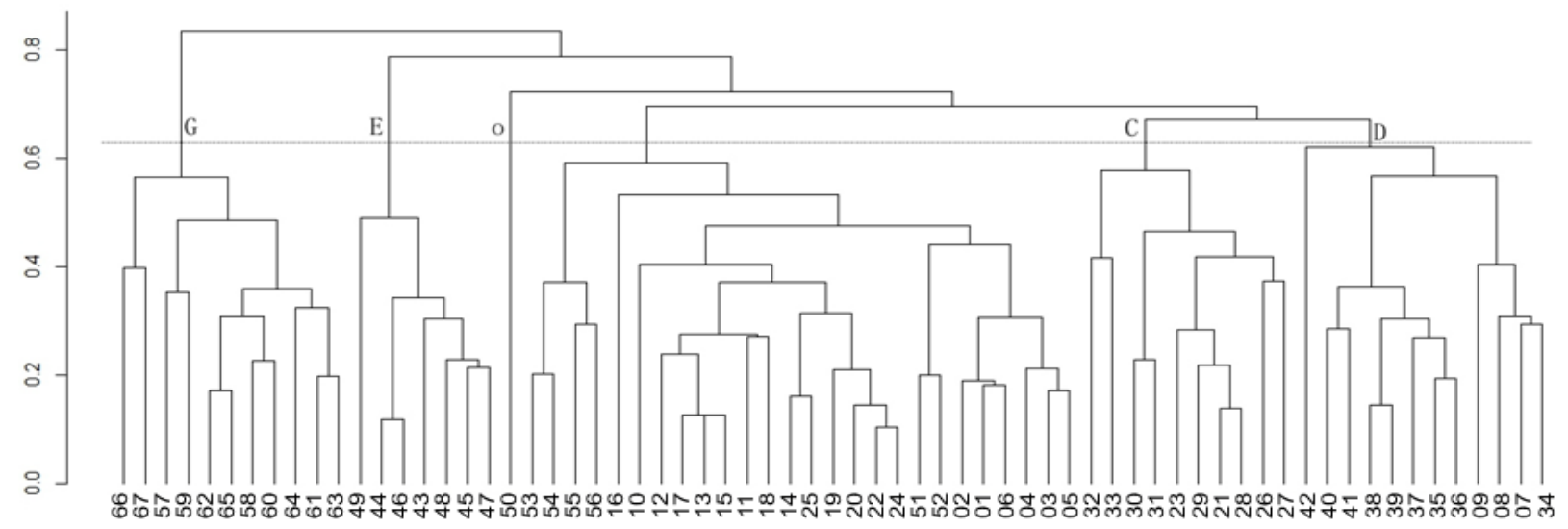

Fig. 5: Clustering tree by Average group linkage method

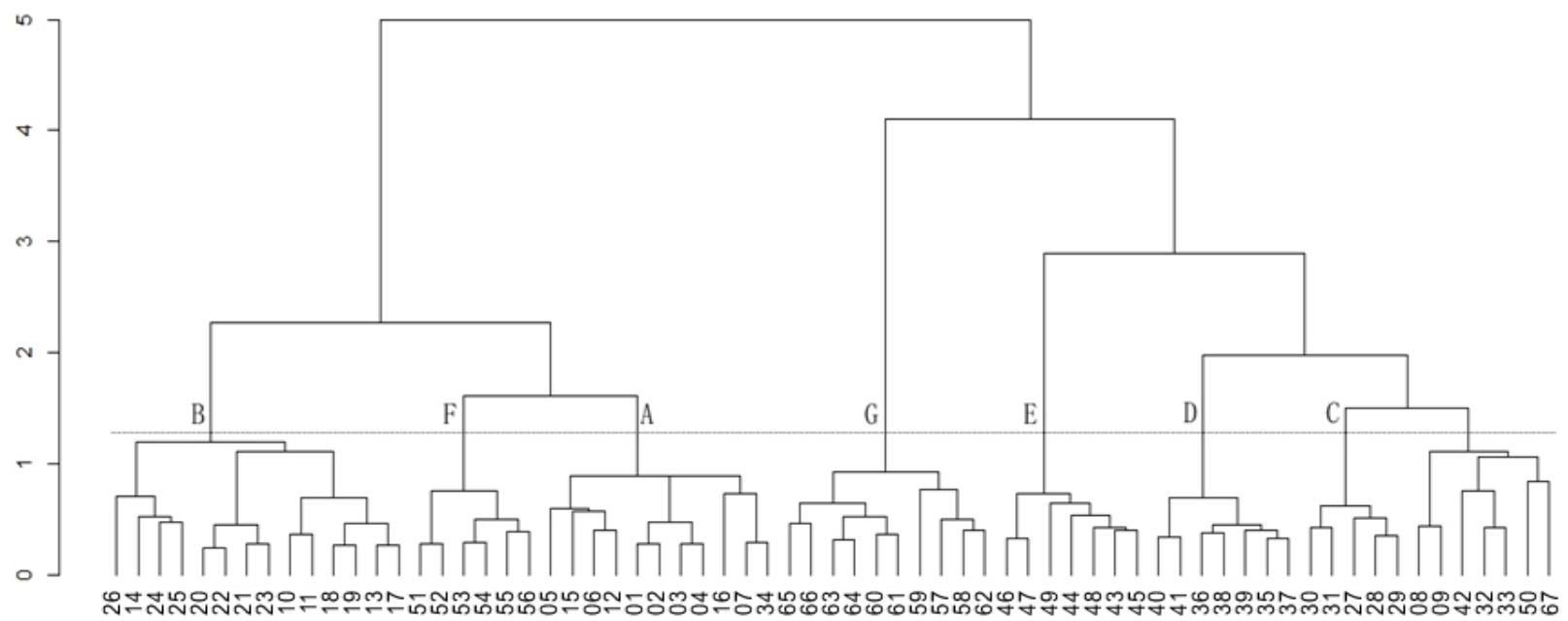

Fig. 6: Clustering tree by Sum of squares method

\section{Discussion}

This study demonstrated that the distribution pattern of medically important insects is consistent with that of phytophagous insects. However it is indisputable fact that the medical insects have a close relationship of food chain with higher animals. Therefore, we can speculated that most insects are phytophagous and the distribution pattern is the same as for plants. Although the feeding habits of mammals are complex and some 
of them are carnivorous, the final food sources are plants. Their distribution pattern should be the same as plants. Thus, medical important insects belong to the bidirection food chain of animals $\rightarrow$ plants $\leftarrow$ phytophagous insects and showed the same results as the total insect distribution. Without doubt this hypothesis requires confirmation from quantitative analysis of plants and mammals and the first step would be to select and standardize the different methods. The comparisons made in this study showed that MSCA method can be useful. We look forward to establishing a consistent model of the distribution patterns of plants, mammals, and insects across the world.

\section{ACKNOWLEDGMENTS}

This study was supported by the key laboratory foundation of Henna (112300413221). We thank also C. B. Cox (UK), H. Kreft (Germany), M.V. Cianciaruso (Brazil), D.R. Gustafsson (USA), P. Vrsansky (Slovak), J.C. Beaucournu (France), T. Najer (Czech), R.J. Whittaker (UK), M. Caesar (France), M. P. Valim (Brazil) for presenting references, or proposing suggestions, or modifying the manuscripts.

\section{References Références Referencias}

1. Acosta, R. (2003) New records of rodent fleas from Queretaro, Mexico (Siphonaptera). Zootaxa, 369: 1-15.

2. Adler, P.H., Crossker, R.W. (2014) World blackflies (Diptera: Simuliidae). http://clemson.edu

3. Balian, E.V., Leveque, C., Segers, H. \& Martens, K., (2008) Freshwater Animal Diversity Assessment. Hydrobiologia, 595:1-637.

4. Beaucournu, J.C. \& González-Acuña, D. (2010) Description de Trochilopsyllatorresmurai n. gen., n. sp. (Siphonaptera: Ceratophyllidae) du Chili, premère mention $d^{\prime}$ une puce parasite $d^{\prime}$ oiseaumouche (Aves:Trochilidae). Parasite, 17: 133-142.

5. Beaucournu, J.C., Belaz, S., Muñoz-Leal, S. \& González-Acuña, D. (2013) A new flea, Ectinorus (Ectinorus) insignisn. sp. (Siphonaptera, Rhopalopsyllidae, Parapsyllinae), with notes on the subgenus Ectinorus in Chile and comments on unciformsclerotization in the Superfamily Malacopsylloidea. Parasite, 20 (35): 1-12.

6. Beaucournu, J.C., Moreno, L. \& González-Acuña, D. (2014) Fleas (Insecta-Siphonaptera) of Chile: a review. Zootaxa, 3900 (2): 151-203.

7. Beccdloni, G. (2014) Cockroach species file. Version 5.0/5.0 http://www.blattodea.speciesFile.org

8. Bejarano, E. E., Estrada, L. G. (2016) Family Psychodidae. In: Wolff, M., Nihei, S. S., De Carvalho, C. J. B. Catalogue of Diptera of Colombia. Zootaxa, 4122 (1): 187-238.
9. Bohn, H., Picker, M., Klass, K.-D. \& Colville, J. (2010) A jumping cockroach from South Africa, Saltoblattellamontistabularis, gen. nov., spec. nov. (Blattodea: Blattellidae). Arthropod Systematics \& Phylogeny, 68 (1): 53-69.

10. Borkent, A. (2014) World species of Biting midges (Diptera: Ceratopogonidae). http://www.inhs.illinois. edu/files

11. Caesar, M., Roy, R., Legendre, F., Grandcolas, P. \& Pellens, R. (2015) Catalogue of Dictyoptera from Syria and neighbouring countries (Lebanon, Turkey, Iraq and Jordan). Zootaxa, 3948 (1): 071-092.

12. Chillcott, J. G, (1960) A revision of the Nearctic species of Fanniinae.Can. Entomologist, Suppl. 14: 1-295.

13. Coscarón, S., Coscarón-Arias, M.C. \& Papavero, N. (2008) Catalogue of NeotropicalDiptera. Simuliidae. Neotropical Diptera, 2: 1-90.

14. Cox, C.B. (2001) The biogeographic regions reconsidered. J. Biogeogr., 28: 511-523.

15. Cox, C.B. (2010) Underpinning global biogeographical schemes with quantitative data. Journal of Biogeography, 37: 2027- 2028.

16. Crespo, F.A., Valverde, A.C. \& Iglesias, M.S. (2010) Catalogue of Blattaria (Insecta) from Argentina. Zootaxa, 2726: 1-33.

17. Crespo, F. A., Valverde, A. D. C. \& Iglesias, M. S. (2015)A new species of Tribonium Saussure, 1862 from the Province of Misiones, Argentina (Blattaria, Blaberidae, Zetoborinae). Zootaxa, 3936 (4): 593599.

18. Currie, D.C., Adler, P.H. (2008) Global diversity of black flies (Diptera: Simuliidae) in freshwater. Hydrobiologia, 595: 469-475

19. Czekanowski, J. (1913) Zarys method statystycznych w zastosowaniu do antropologii [An outline of statistical methods applied in anthropology]. Warszawa: Towarzystwo Naukowe Warszawskie.

20. Darsie, R.F., Jr.; Ward, R.A. (2005) Identification and geographical distribution of the mosquitoes of North America, North of Mexico. Second Edition. University Press of Florida, $384 \mathrm{pp}$.

21. De Carvalho, C.J.B., Couri, M.S., Pont, A.C., Pamplona, D.M. \& Lopes, S.M., (2005) A catalogue of the Muscidae (Diptera) of the Neotropical Region. Zootaxa, 860: 1-282.

22. De Mello-Patiu, C. A. (2016) Family Sarcophagidae. In: Wolff, M., Nihei, S. S., De Carvalho, C. J. B. Catalogue of Diptera of Colombia. Zootaxa, 4122 (1): 884-903.

23. Durden, L.A., Musser, G.G. (1994) The sucking lice (Insecta: Anoplura) of the World: A taxonomic checklist with records of mammalian host and geographical distributions. American Museum of Natural History, 218, 90pp. 
24. El-Ahmed, A., Nasser, M.G., Shobrak, M. \&Dik, B. (2012) First records of the chewing lice (Phthiraptera) associated with European bee eater (Meropsapiaster) in Saudi Arabia. Journal of the Egyptian Society of Parasitology, 42 (3): 525-533.

25. Evans, G.A. (2007) The whiteflies (Hemiptera: Aleyrodidae) of the World and their host plants and natural enemies. 708pp. http://www. keys.lucidcentral.org/keys/y3.

26. Evenhuis, N.L. (2016) Catalog of the Diptera of the Australasian and Oceanian regions. http://www.hbs. bishopmuseum.org.

27. Feliciangeli, M. D. (2006) On the phlebotomine sandflies (Diptera: Psychodidae: Phlebotominae) with special reference to the species known in Venezuela. Acta Biol. Venez., 26(2): 61-80.

28. Fuenzalida, A. D., Quintana, M. G. (2017) Description of Pintomyiasalomoni sp. n., a new phlebotomine species from northwest Argentina. Medical and Veterinary Entomology, 31(2): 214-219.

29. GBIF, (2019a) Coleoptera. http://gbif.org/species/ 1470.

30. GBIF, (2019b) Diptera. http://gbif.org/species/811.

31. GBIF, (2019c) Hemiptera. http://gbif.org/species/ 809.

32. GBIF, (2019d) Hymenoptera. http://gbif.org/species $/ 1457$.

33. GBIF, (2019e) Lepidoptera. http://gbif.org/species 1797 .

34. Grisales, D., De Carvalho, C. J. B. (2016)Family Fanniidae. In: Wolff, M., Nihei, S. S., De Carvalho, C. J. B. Catalogue of Diptera of Colombia. Zootaxa, 4122 (1): 807-813.

35. Gustafsson, D. R. \& Bush, S. E. (2014) Three new species of chewing lice of the genus Emersoniella Tendeiro, 1965 (Insecta: Phthiraptera: Ischnocera: Philopteridae) from Papua New Guinean kingfishers and kookaburras (Aves: Coraciiformes: Alcedinidae). Zootaxa, 3796 (3): 528-544.

36. Gustafsson, D. R. \& Bush, S. E. (2015) Four new species of BrueeliaKéler, 1936 (Phthiraptera: Ischnocera: Philopteridae) from African songbirds (Passeriformes: Sturnidae and Laniidae).Zootaxa, 4013 (4): 503-518.

37. Gustafsson, D. R., Tsurumi, M. and Bus,h S. E. (2015) The chewing lice (Insecta: Phthiraptera: Ischnocera: Amblycera) of japanese pigeons and doves (Columbiformes), with descriptions of three new species. J. Parasitol., 101(3): 304-313.

38. Hastriter, M. W., Haas, G. E. \& Wilson, N. (2006) New distribution records for Stenoponiaamericana (Baker) and StenoponiaponeraTraub and Johnson (Siphonaptera: Ctenophthalmidae) with a review of records from the Southwestern United States. Zootaxa, 1253: 51-59.

39. Hastriter, M.W. \& Sage, R.D. (2011) Description of a new species of Ectinorus (E. spiculatus)
(Siphonaptera, Rhopalopsyllidae) from Argentina and a review of the subgenus IchyonusSmit, 1987.ZooKeys, 124: 1-18.

40. Hellenthal, R.A. \& Price, R.D. (2003) The genus Myrsidea Waterston (Phthiraptera: Menoponidae) from bulbuls (Passeriformes: Pycnonotidae), with descriptions of 16 new species. Zootaxa, 354: 1-20.

41. Henriques, A. L. (2016) Tabanidae (Diptera) of the American Museum of Natural History Collection. Zootaxa, 4137 (2): 151-186.

42. Herman, L.H., Ales, S. (2001) Catalog of the Staphylinidae (Insecta: Coleoptera), 1758 to the end of the second millennium. Vol. I-VII. Bulletin of the American Museum of Natural Hostory.265: 1-4218.

43. Holt, B.G. et al., (2013) An update of Wallace's zoogeographic regions of the World. Science, 339: 74-78.

44. Hopkins, G. H. E., Rothschild, M. (1953-1971)An Illustrated Catalogue of the Rothschild Collection of Fleas (Siphonaptera) in the British Museum (Natural History) with Keys and Short Descriptions for the Identification of Families, Genera, Species and Subspecies of the Order. Vol. I-V. London: Brit. Mus. (Natur. Hist.).

45. Huerta, H., Grogan, W. L., Jr. (2017)New species and new records of predaceous midges in the genera, Schizonyxhelea Clastrier and Stilobezzia Kieffer from Mexico (Diptera: Ceratopogonidae). Zootaxa, 4294 (4): 401-418.

46. Iorio, O.D. (2012) The bat bugs (Hemiptera: Cimicidae) from Argentina: geographic distributions, hosts, and new records. Zootaxa, 18.Jun. 48-55.

47. Ivković, M., Kúdela, M., Kúdelová, T. (2016)Blackflies (Diptera: Simuliidae) in Croatia: species richness, distribution and relationship to surrounding countries. Zootaxa, 4109 (1): 16-30.

48. Jaccard, P. (1901) Distribution de la flore alpine dans le bassin des Dranses et dans quelques régions voisines. Bull. Soc. Vaud. Sci. Nat., 37: 241-272.

49. Knight, K.L., Stone, A. (1977) A catalog of the mosquitoes of the World (Diptera: Culicidae). Entomological Society of America, Maryland. 621pp.

50. Kounek, F., Sychra, O., Capek, M. \&Literak, I. (2013) Chewing lice of genus Myrsidea (Phthiraptera: Menoponidae) from Turdidae (Passeriformes) of Costa Rica, with descriptions of seven new species. Zootaxa, 3620 (2): 201-222.

51. Kreft, H., Jetz, W. (2010) A framework for delineating biogeographical regions based on species distributions. Jounal Biogeography, 37(11): 20292053.

52. Krolow, T. K., Henriques, A. L. (2010) Taxonomic revision of the New World genus Chlorotabanus Lutz, 1913 (Diptera: Tabanidae). Zootaxa, 25 Oct. $1-40$. 
53. Lewis, R.E. \& Eckerlin, R.P. (2013) A review of the mustelid-infesting fleas in the family Ceratophyllidae (Insecta: Siphonaptera). Annals of Carnegie Museum, 81: 119-134.

54. Mattingly, P. F., (1962) towards a zoogeography of the mosquitoes. Syst. Assoc. Publ. 4: 17-36.

55. Mey, E. (2004) ZurTaxonomie, Verbreitung und parasitophyletischer Evidenz des PhilopterusKomplexes (Insecta, Phthiraptera, Ischnocera). OrnithologischerAnzeiger, 43: 149-203.

56. Moor, F.C.de, Ivannov, V.D. (2008) Global diversity of caddisflies (Trichoptera: Insecta) in freshwater. Hydrobiologia, 595: 393-407.

57. Morse, J.C., Barnard, P.C., Holzenthal, K.W., Hulsman, J., Ivanov, V.D., Moor, F.C., Tanide, K., Welles A. \& Wichard, W. (2011)Trichoptera World checklist. http://www.entweb.clemson.edu/database/trichopt/index.htm

58. Najer, T., Sychra, O., Kounek, F., Papousek, I. \& Hung, N. M. (2014) Chewing lice (Phthiraptera: Amblycera and Ischnocera) from wild birds in southern Vietnam, with descriptions of two new species. Zootaxa, 3755 (5): 419-433.

59. Najer, T., Gustafsson, D. R. \& Sychra, O. (2016) Two new species of Philopteroides (Phthiraptera: Ischnocera: Philopteridae) of the beckeri speciesgroup, from New Guinean painted berrypeckers (Aves: Passeriformes: Paramythiidae). Zootaxa, 4139 (4): 527-541.

60. Natarajan, R., Rajavel, A. R., Jambulingam, P. (2017) Descriptions of three new species of Uranotaenia (Pseudoficalbia) Diptera: Culicidae) from India. Zootaxa, 4227 (2): 251-265.

61. Olson, D. M. et al. (2001) Terrestrial ecoregions of the worlds: A new map of life on Earth. Bioscience, 51(11): 933-938.

62. Palma, R. L. \& Peck, S. B. (2013) An annotated checklist of parasitic lice (Insecta: Phthiraptera) from the Galápagos Islands. Zootaxa, 3627: 1-87.

63. Peixoto, F. P., Villalobos, F., Melo, A. S., Diniz-Filho, J. A. F., Loyola, R., Rangel, T. F., Cianciaruso, M. V. (2017) Geographical patterns of phylogenetic betadiversity components in terrestrial mammals. Global Ecology and Biogeography, 26: 573-583.

64. Pellens, R. and Grandcolas, P. (2008) Catalogue of Blattaria (Insecta) from Brazil. Zootaxa, 1709: 1-109.

65. Pérez, S., De Carvalho, C. J. B. (2016) Family Muscidae. In: Wolff, M., Nihei, S. S., De Carvalho, C. J. B. Catalogue of Diptera of Colombia. Zootaxa, 4122 (1): 814-853.

66. Pickering, J. (2014) Discover life: Mallophaga. $\mathrm{http} / / \mathrm{www}$.discoverlife.org/mp

67. Pont, A.C. (2013) The Fanniidae and Muscidae (Diptera) described by Paul Stein (1852-1921). Zoosystematics and Evolution, 89: 31-166.
68. Price, R.D., Hellenthal R.A., Palma R.L., Johnson K.P. \& Clayton, D.H. (2003) The Chewing Lice. World Checklist and Biological Overview. Illinois Natural History Survey, Special Publication 24: $1-501$.

69. Procheş, Ş. (2005) The world's biogeographical regions: cluster analyses based on bat distributions. Journal of Biogeography, 32(4): 607-614.

70. Procheş, Ş., Ramdhani, S. (2012) The world's zoogeographical regions confirmed by cross-taxon analyses. Bioscience 62(3): 260-270.

71. Rognes, K. (2011) A review of the monophyly and composition of the Bengaliinae with the description of a new genus and species, and new evidence for the presence of Melanomyinae in the Afrotropical Region (Diptera, Calliphoridae). Zootaxa, 13 Jul. 1-60.

72. Roth, L.M. (2003) Systematics and phylogeny of cockroaches (Dictyoptera: Blattaria). Oriental Insects, 37: 1-186.

73. Rueda, M., Rodríguez, M. Á. and Hawkins, B. A. (2013) Identifying global zoogeographical regions: lessons from Wallace. Jounal of Biogeography, 40(12): 2215-2225.

74. Ryckman, R. E., Bentley, D. G. and Archbold, E. F. (1981) The Cimicidae of the Americas and oceanic islands, a checklistand bibliography. Bulletin of the Society of Vector Ecologists, 6: 93-142.

75. Sánchez-Montes, S., Guzmán-Cornejo, C., LeónPaniagua, L. \& Rivas, G. (2013) A checklist of sucking lice (Insecta: Phthiraptera: Anoplura) associated with Mexican wild mammals, including geographical records and a host-parasite list. Zootaxa, 3722 (2): 183-203.

76. Seccombe, A.K., Ready, P.D. and Huddleston, L.M. (1993) A Catalogue of Old World Phlebotomine Sandflies (Diptera: Psychodidae, Phlebotominae). The Natural History Museum. 60pp.

77. Shen, Q. (2014) Multivariate similarity clustering analysis for distribution of the medical insect in China. Acta Parasitologicaet Medica Entomolofica Sinica, 21(3): 165-171.

78. Shen, X.C., Wang, A. P. (2008a) A simple formula for multivariate similarity coefficient and its contribution rate in analysis of insect fauna. Journal of Henan Agricultural Sciences, (7): 67-69.

79. Shen, X.C, Sun, H., Zhao, H.D. (2008b) A discussion about the method for multivariate similarity analysis of fauna. Acta Ecologica Sinica, 28(2): 849-854.

80. Shen, X.C., Ren, Y.D., Wang, A.P. \& Zhang, S.J. (2010a) A multivariate similarity clustering analysis for geographical distribution of insects, spiders and mites in Henan province. Acta Ecologica Sinica, 30: 4416-4426.

81. Shen, X.C., Sun H. \& Ma, X.J. (2010b) The Multivariate similarity clustering analysis for 40000 
species of insect and spider in China. Journal of Life Sciences, 4(2): 35-40.

82. Shen, X.C., Liu, X.T., Ren, Y.D., Shen, Q., Liu, X.G., Zhang, S.J. (2013a) The multivariate similarity clustering analysis and geographical division of insect fauna in China. Acta Entomologica Sinica, 56(8): 896-906.

83. Shen, X.C., Zhang, B.S., Zhang, F. \& Liu, X.T. (2013b) Worldwide distribution and multivariate similarity clustering analysis of spiders. Acta Ecologica Sinica, 33: 6795-6802.

84. Shen, X.C. et al. (2015) Insect geography of China. Henan Science and Technology Press, Zhengzhou, China. 980pp.

85. Shen, X.C., Ren, Y.D., Shen, Q., You, Z.X.et al. (2018) The Macroscopic characteristics of distribution of global terrestrial biota. International Journal of Ecology, 7(2): 98-128. DOI: 10.12677/ije.2018.72014

86. Silver, J. (2004) World Culicidae. http://www. dipteraculicidae.Ocatch.com

87. Simpson, G.G. (1943) Mammals and the nature continents. Am. J. Sci., 241: 1-31.

88. Spinelli, G. A., Wolff, M. (2016) Family Ceratopogonidae. In: Wolff, M., Nihei, S. S., De Carvalho, C. J. B. Catalogue of Diptera of Colombia. Zootaxa, 4122 (1): 98-141.

89. Sørensen, T. (1948) A method of establishing groups of equal amplitude in plant sociology based on similarity of species centent and its application to analysis of the vegetation on Danish commons. Biol. Skr., 5:1-34.

90. Szelag, E. A., Filho, J. D. A., Rosa, J. R., Parras, M. A., Quintana, M. G., Salomon, O. D. (2016) Argentinian phlebotomine fauna, new records of Phlebotominae (Diptera: Psychodidae) for the country and the province of Chaco. Zootaxa, 4139 (3): 427-430.

91. Szymkiewicz, D. (1934) Une contribution statistique a la geigraphie floristique. Acta Soc. Bot. Pol., 11: 3.

92. Taeger, A., Blank, S.M., Liston, A.D. (2010) World catalog of Symphyta (Hymenoptera). Zootaxa, 2580: 1-1064.

93. Takano, O. M., Mitchell, P. S., Gustafsson, D. R., Adite, A., Voelker, G. and Light, J. E. (2017) An assessment of host associations, geographic distributions, and genetic diversity of avian chewing lice (Insecta: Phthiraptera) from Benin. J. Parasitol., 103(2):152-160.

94. Takaoka, H., Sofian-Azirun, M., Ya'cob, Z., Chen, C. D., Lau, K. W., Low, V. L., Pham, X. D., Adler, P. H. (2017)The black flies (Diptera: Simuliidae) of Vietnam. Zootaxa, 4261 (1): 1-165.

95. Tantawi, T. I., Whitworth, T. L., Sinclair, B. J. (2017) Revision of the Nearctic Calliphora RobineauDesvoidy (Diptera: Calliphoridae). Zootaxa, 4226 (3): 301-347.
96. Usinger, R.L. (1966) Monograph of CimicidaeVol.VII. Entomological Society of America, Maryland, pp292-490.

97. Valim, M.P. (2009) Type specimens of lice (Insecta: Phthiraptera) held in the Museu de Zoologia da Universidade de São Paulo, Brazil. Papéis Avulsos de Zoologia, 49 (17): 197-219.

98. Valim, M.P. \& Palma, R.L. (2013) Three new species of the genus Philopteroides Mey, 2004 (Phthiraptera, Ischnocera, Philopteridae) from New Zealand. ZooKeys, 297: 71-89.

99. Valim, M. P. \& Silveira, L. F. (2014) A new species and five new records of chewing lice (Insecta: Phthiraptera: Ischnocera) from an isolated population of the solitary tinamou Tinamussolitarius (Aves: Tinamiformes). Zootaxa, 3838 (1): 127-142.

100. Vashchonok, V., Medvedev, S. (2013) Fleas (Siphonaptera. http://www.zin.ru/Animalia/ Siphonaptera

101. Vidlička, L'. (2013) Cockroaches (Blattaria) of Ecuador-checklist and history of research. Zootaxa, 3599 (5): 401-445.

102. Vidlicka, L. \& Majzlan, O. (1997) Revision of the megerlei-group of the cockroach genus Phyllodromica Fieber (Blattaria: Blattelidae, Ectobiinae). EntomologicaScandinavica,28, 163-173.

103. Vidlička, L., Vršanský, P., Kúdelová, T., Kúdela, M., Deharveng, L. \& Hain, M. (2017) New genus and species of cavernicolous cockroach (Blattaria, Nocticolidae) from Vietnam. Zootaxa4232 (3): 361375.

104. Vršanský, P. (2010) A new genus and species of cockroach (Blattida: Phyloblattidae) from the Permian/Triassic boundary beds of Tunguska Basin in eastern Siberia, Russia. Zootaxa, 2353: 55-61.

105. Vršanský, P. \& Aristov, D. (2012) Enigmatic Late Permian cockroaches from Isady, Russia (Blattida: Mutoviidae fam. n.). Zootaxa, 3247: 19-31.

106. Vršanský, P., Vidǔka, L'., Barna, P., Bugdaeva, E. \&Markevich, V. (2013) Paleocene origin of the cockroach families Blaberidae and Corydiidae: Evidence from Amur River region of Russia. Zootaxa, 3635 (2): 117-126.

107. Wallace, A R. (1876) The geographical distribution of animals. Macmillan, London.

108. Ward, J.H. (1963) Heirarchical grouping to optimise an objective function. J. Amer. Stat. Ass., 58: 236 244.

109. Whittaker, R. J., Riddle, B. R., Hawkins, B. A. Ladle, R. J. (2013) The geographical distribution of life and the problem of regionalization: 100 years after Alfred Russel Wallace. Journal of Biogeography, 40(12): 2209- 2214

110. Wolff, M., Miranda-Esquivel, D. R., MoncadaAlvarez, L. I. (2016) Family Simuliidae. In: Wolff, M., 
Nihei, S. S., De Carvalho, C. J. B. Catalogue of Diptera of Colombia. Zootaxa, 4122 (1): 154-177.

111. Zhang R.Z. (2011) Zoogeograpby of China. Science Press, Beijing, China. 330pp. 